\title{
CONSECUTIVE SENTENCES IN SINGLE PROSECUTIONS: JUDICIAL MULTIPLICATION OF STATUTORY PENALTIES*
}

To insure that certain antisocial behavior does not escape the reach of the criminal law, legislatures often proscribe the various elements which comprise an undesirable course of conduct. The result has been a proliferation of offenses capable of commission by a single activity. On the one hand, a particular statute may isolate and condemn a number of steps in a given process ; such blanket prohibition facilitates conviction of participants in any aspect of the deviant conduct. ${ }^{2}$ On the other hand, distinct statutes apparently unrelated to one another may overlap to effect a mutual proscription of an individual action. ${ }^{3}$ While, in either case, indictment on more than one count may aid both defendant and prosecutor, imposition of consecutive multiple sentences ${ }^{5}$ may thwart legislative intent. For the equation of plead-

*Gore v. United States, 244 F.2d 763 (D.C. Cir. 1957), cert. granted, 355 U.S. 903 (1958).

1. E.g., the federal statutory scheme dealing with counterfeiting condemns possessing plates and concealing, manufacturing and possessing counterfeit money as well as actually buying, selling, exchanging, transferring, receiving, delivering or passing counterfeit money. 18 U.S.C. $\$ \$ 471-74$ (1952).

2. See, e.g., United States v. Petrone, 185 F.2d 334 (2d Cir. 1950), cert. denicd, 340 U.S. 931 (1951) (possession of counterfeit money).

3. Pereira v. United States, 3.7 U.S. 1. (1954), provides an example of overlapping statutes, enacted at different times, held applicable to the same transaction. Defendants deposited a fraudulently obtained check in a Texas bank which mailed it to California for clearing. By "causing stolen property to be transported in interstate commerce," they were found to have violated the National Stolen Property Act, 18 U.S.C. $\$ 2314$ (1952), as well as the mail fraud statute, 18 U.S.C. $\$ 1341$ (1952).

4. While prosecutors have been criticized as "overzealous" in use of multiple count indictments, Note, 7 Brooklyn L. Rev. 79, 82 (1937), the practice does preserve alternatives upon failure of proof or variance on one count, see Leflar, The Criminal Procedure Reforms of 1936-Twenty Years After, 11 ARK. L. Rev. 117, 127-28 (1957). And defendants are thus insulated from multiple prosecutions on single counts. Statutes frequently provide for joinder of alleged violations in criminal trials relating to a single act or transaction. See, e.g., Fed. R. Crim. P. \&(a); N.Y. Cone Crim. Proc. § 279; Wis. Stat. \$ 939.65 (1955). See also ALI Model PeNal Code $\$ 1.08(2)$ (Tent. Draft No. 5,1955 ) (hereinafter cited as Model PENAL Code) (compulsory joinder); Comment, 65 YALE L.J. 339, 359-61 (1956).

5. Criminal conduct can be described in terms of act, intent, consequences and law; and multiple sentence problems may arise where an indictment, in separate counts, varies one or more of the elements while the others remain constant. Among the possible variations are: (1) the same physical act allegedly violating several statutes; (2) defendant's continuing acts separately charged as violating a single statute; (3) one statute and one act producing multiple consequences. See ALI, Administration of the CRIMINal Law 33-61 (Official Draft 1935) (hereinafter cited as ALI DRAFT), for a list of eight variations followed by a collection of cases. This Note will only deal with multiple sentence problems arising where one act allegedly violates different statutory provisions. 
able with punishable offenses can yield a punishment far exceeding the intended sanction. ${ }^{6}$

Federal narcotics laws, for example, condemn each component of an illicit transaction in an effort to restrict drug traffic to prescribed channels. ${ }^{7}$ The Harrison Act prohibits the purchase, sale, distribution, dispensing, exchange or gift of narcotics unless accompanied by treasury order forms and tax stamps, both issued only to registered dealers. ${ }^{8}$ In addition, the purchase, sale or concealment of illegally imported drugs, as well as the importation itself, is a felony. ${ }^{9}$ Thus, a single sale may and usually does elicit an indictment on several counts. ${ }^{10}$ And, aided by the statutory presumption that possession

6. E.g., in United States v. Dicario, 8 U.S.C.M.A. 353, 361, 24 C.M.R. 163, 171 (1957), defendant's act of stealing letters from the mail violated both a larceny statute and the federal mail law. The court found that "the offenses are not separately punishable." But the idea that several offenses separately charged and proved may constitute a single "offense" for purposes of punishment is not easily accepted. Thus, the dissenting opinion accused the majority of ruling that "interference with the mails is the same offense as larceny." Nonethelesss, the indictable-punishable offense dichotomy has long been accepted in lesser included offense cases. Defendant may be charged with and found guilty of both the lesser and the greater offense, yet there is but a single punishable offense. See, e.g., Costner v. United States, 139 F.2d 429 (4th Cir. 1943) (reversing consecutive sentences where assault with intent to rob was a lesser offense included in robbery); Commonwealth ex rel. Shaddock v. Ashe, 340 Pa. 286, 17 A.2d 190 (1941) (while assault and battery may be joined in the same indictment with rape, defendant may only be punished for the more serious crime). See also Prince v. United States, 352 U.S. 322 (1957) (for purposes of punishment, the crime of entering a bank with intent to commit a robbery merges with the crime of robbery); Stevens v. McClaughry, 207 Fed. 18, 21 (Sth Cir. 1913); Commonwealth ex rel. Ciampoli v. Heston, 292 Pa. 501, 141 Atl. 287 (1928).

7. H.R. Rep. No. 23, 63d Cong., 1st Sess. (1913) ; S. Rep. No. 258, 63d Cong., 2d Sess. (1914); see King, Narcotic Drug Laws and Enforcement Policies, 22 LAW \& Contemp. Prob. 113-1S (1957) ; Comment, 62 Yale L.J. 751, 765-69 (1953). Congress did not intend that sales to nonmedical addicts be within legitimate channels. See INT. REv. CoDE of 1954, $\$$ 4704(b) (1), 4705(c) (1) (exemption from written order form and tax stamp requirements if drugs "issued for legitimate medical uses" or dispensed "in the course of his [doctor's] professional practice only"); cf. Direct Sales Co. v. United States, 319 U.S. 703 (1943).

S. INT. Rev. CODE of 1954, $\$ \$ 4704-05,4724$.

9. 35 Stat. 614 (1909), as amended, 21 U.S.C. $\$ 173$ (1952).

10. See, $\epsilon . g$, the report on narcotics indictments in the District of Columbia for July 1, 1954, to June 30, 1955, contained in Hearings Before the Subcommittee on Traffic in, and Control of Narcotics of the Honse Committee on Ways and Means, 84th Cong., 2d Sess. 1252-58 (1956). Eighty-five per cent of the cases listed clearly involved multiple counts, and the information on the remaining $15 \%$ is inconclusive. The consistent practice was to charge violations of both the Harrison Act, INT. REv. CoDE of 1954, $\$ \$ 4701-36$, and the Narcotic Drugs Import and Export Act, 35 STAT. 614 (1909), as amended, 21 U.S.C. $\$ \$ 173-74$ (1952). See Hearings, supra at 1158-81. Even where violation of only one act was charged, several counts may have been used. Reported narcotics appeals cases in the various circuits indicate that such practice is widespread. See, c.g., Long v. United States, 235 F.2d 183 (6th Cir. 1956); Martinez v. United States, 220 F.2d 740 (1st Cir. 1955); United States v. Brown, 207 F.2d 310 (7th Cir. 1953). Nor is this method of pleading a recent innovation. See narcotics indictment form in Hopkins, The New Federal Penal Code 932-35 (1927) (five counts). 
evidences multiple violations, ${ }^{11}$ the government regularly obtains multiple convictions. $^{12}$

Where multiple convictions induce consecutive sentences, defendants seeking relief frequently invoke the constitutional injunction against double jeopardy. ${ }^{13}$ Contending that they have been twice punished for a single offense, ${ }^{14}$ such defendants misconceive the protection afforded by that safeguard. Double jeopardy presumably evolved as a reaction against the prodigious prosecution advantages and horrendous sentences of the early common law. ${ }^{15}$ It is currently calculated to secure finality in criminal litigation and to protect defendants from the threat, harassment and stigma of repeated criminal trials.10 Neither the historical nor modern functions of the doctrine encompass more

11. See Statement of Assistant Attorney General Warren Olney, III, in Hearings, supra note 10, at 1195: "Because of the various presumptions of guilt arising from the possession of narcotics in several of the narcotic statutes the prosecution of narcotic violators once they have been apprehended actually presents no great problem. As a matter of fact it is our opinion that narcotic violators are frequently convicted on evidence that would not suffice in most other types of cases." Possession of narcotics in an unstamped container is prima facie evidence of unlawful purchase, sale, dispensation or distribution, INT. REv. CODE of 1954, $\S 4704$ (a) ; and the same possession may in a single case be deemed sufficient evidence to authorize conviction for fraudulently or knowingly importing, receiving, concealing, buying, selling and facilitating the transportation of illicit drugs, 35 STAT. 614 (1909), as amended, 21 U.S.C. $\$ 174$ (Supp. IV, 1957); see, e.g., Martinez v. United States, supra note 10; United States v. Brown, supra note 10.

12. In 1954 , over $86 \%$ of the narcotics cases tried in the federal courts resulted in convictions-in over half of the cases, guilty pleas were entered. Hearings, supra note 10 , at 1198. In the District of Columbia in 1955, convictions were obtained in $92 \%$ of the cases that went to trial. Id. at 1259. The conviction rate in New York's Southern District was $99.2 \%$. Id. at 494.

13. "[N]or shall any person be subject for the same offense to be twice put in jeopardy of life or limb; ..." U.S. Const. amend. V. For a collection of similar provisions in state constitutions and statutes, see ALI DRAFT 62-72.

14. Albrecht v. United States, 273 U.S. 1, 11 (1927) (selling illicit liquor and possession of the same liquor) ; Morgan v. Devine, 237 U.S. 632, 637 (1915) (breaking and entering with intent to steal mail and stealing mail); Michener v. United States, 157 F.2d 616, 617 (8th Cir.), rev'd per curiam, 331 U.S. 789 (1947) (consecutive sentences on counts of procuring and possessing counterfeiting plates); Kendrick v. United States, 238 F.2d 34, 36 (D.C. Cir. 1956) (assault with a deadly weapon and carrying an unlicensed weapon); United States v. Johnson, 235 F.2d 159, 161 (7th Cir. 1956) (purchase and possession of narcotics incidental to sale, and sale of, narcotics).

15. See Comment, 65 YaLE L.J. $339-44$ (1956) ; Note, 57 YaLE L.J. 132-33 (1947). At common law, an accused felon was not allowed counsel, could not see the indictment and could neither testify nor call witnesses in his behalf. Acquittals were rare; and conviction meant death, dismemberment or banishment. RAdIN, ANGLO-AMERRICAN LEGAL History 228-29, 236-38 (1936); 9 HoldswORTH, History of English LAw 223-36 (2d ed. 1938) ; 1 Stephen, Criminal Law of England c. 11 (1883).

16. Green v. United States, 355 U.S. 184, 187-88 (1957): "The underlying idea, one that is deoply ingrained in at least the Anglo-American system of jurisprudence, is that the State with all its resources and power should not be allowed to make repeated attempts to convict an individual for an alleged offense, thereby subjecting him to embarrassment, expense and ordeal and compelling him to live in a continuing state of anxiety and in- 
than prohibition of successive prosecution. ${ }^{17}$ Moreover, since the legislature may, consonant with legitimate penological principles, authorize consecutive

security, as well as enhancing the possibility that even though innocent he may be found guilty." See also State v. Cooper, 13 N.J.L. 361, 370, 375 (Sup. Ct. 1833).

By limiting double jeopardy to situations of "exact and complete identity in the two offenses charged," narrow judicial interpretation of the "same offense" has in many cases effectively emasculated Fifth Amendment protection. See State v. Hoag, 21 N.J. 496, 122 A.2d 625 (1956), aff'd, 26 U.S.L. WEEK 4307 (U.S. May 19, 1958) ; People v. Ciucci, 8 I11. 2d 619, 137 N.E.2d 40 (1956), aff'd per curiam, 26 U.S.L. WeEK 4340 (U.S. May 19, 1958) ; State v. Nash, 86 N.C. 650,653 (1882). Thus, acquittal on a charge of larceny of an automobile may not be a bar to prosecution for "taking, using and operating an automobile on a public highway without the owner's consent," even though both "offenses" related to the same activity. Eastway v. State, 189 Wis. 56, 206 N.W. 879 (1926). On the other hand, the "same transaction" approach adopted in a minority of jurisdictions can yield protection against such prosecutions. See State v. Cooper, supra. See also Comment, 65 YAIE L.J. 339, 340 n.5 (1956) (former jeopardy prohibition of early common law, in practice, preciuded retrial of any aspect of a factual transaction). The same transaction test, however, has been erratically and inconsistently applied. See ALI DRAFT 29 (analyzing Georgia cases).

Policies underlying criminal double jeopardy provisions roughly parallel those of res judicata in civil cases. "No one shall be twice vexed for the same cause" (nemo debet bis z'exari pro una et eadem causa) is the common antecedent of civil res judicata and criminal autrefois acquit and autrefois convict, the common-law equivalents of the plea of former jeopardy. See 4 Blackstone, Commentaries $* 335$; Perkins, Crminal Law and Procedure 650 (1952); Ali Draft 7. For discussion of res judicata, see Clark, Modern Pleadring 761-66 (1951). However, a res judicata approach is of limited utility in the criminal law, for the verdict's generality makes determination of the necessarily decided issues difficult. See, e.g., State v. Hoag, 21 N.J. 496, 504-06, 122 A.2d 628, 632-33 (1956), aff'd, 26 U.S.L. WeEk 4307, 4309-10 (U.S. May 19, 1958); Rouse v. State, 202 Md. 481, 488-90, 97 A.2d 285, 288-89 (1952) ; Lugar, Criminal Law, Double Jeopardy and Res Judicata, 39 Iowa L. REv. 317, 332-44 (1954). A plea of res judicata, however, has successfully barred a second criminal prosecution in those few cases where the statement directing verdict for defendant or the charge to the jury was sufficiently specific to preclude doubt of the necessarily found facts. See Sealfon v. United States, 332 U.S. 575 (1948).

The Model Penal Cone $\$ 1.10$ would bar suit even though the former prosecution was for a different "offense" if the subsequent prosecution is for "(a) any offense of which the defendant could have been convicted on the first prosecution; or (b) any offense with which the defendant should have been charged on the first prosecution under the compulsory joinder provision of Section 1.08."

17. Holiday v. Johnston, 313 U.S. 342,349 (1941.) (dictum): "[T]he erroneous imposition of two sentences for a single offense, of which the accused has been convicted, or as to which he has pleaded guilty, does not constitute double jeopardy." Calvaresi v. United States, 216 F.2d 891, 902 (10th Cir. 1954): "[T]he Fifth Amendment is not against imposition of a double sentence for the same offense, but is against trying one for a second time for the same offense." White v. Pescor, 155 F.2d 902 (8th Cir. 1946). See 3 Story, Commentaries on the Constitution 659 (1833) (jeopardy refers to being twice "tried"). The Amendment as originally proposed by Madison, see 1 AnNaIs of Cong. 451-52 (June 8, 1789), 781-82 (Aug. 17, 1789) (Gales \& Seaton 1834) ("no person shall be subject, except in cases of impeachment, to more than one punishment or one trial for the same offense"), and in its final form, was clearly intended to be a statement of established common-law principles, and as such was understood to be a prohibition of multiple trials. See Mr. Justice Frankfurter's discussion of the amendment's 
sentences when a single act violates several statutory provisions, double jeopardy should not be extended beyond its traditional ambit. ${ }^{18}$

history in Green v. United States, 355 U.S. 184, 200-02 (1957) (dissenting opinion). Multiple count indictments were not unusual at common law, see 2 HALE, PleAs of the Crown 173 (Wilson ed. 1778); 1 ChitTy, Criminal LaW 167-72 (1819); STaRkie, Cruminal Pleading 42-47 (1824), and consecutive sentencing was possible, see Rex v. Williams, 1 Leach 529, 536, 168 Eng. Rep. 366, 370 (Twelve Judges 1790) ; 1 C Criminal. LAw 494 (1819), although unnecessary because of the capital nature of most offenses. Nevertheless, pleas of autrefois acquit or autrefois convict apparently were considered improper unless a former trial and verdict were shown. See Case of Swan, Fost. 104, 168 Eng. Rep. 52 (Chelmsford Assizes 1751).

While the Supreme Court has occasionally granted habeas corpus review in multiple sentence cases, the double jeorardy contentions presumably justifying the grant of review have been uniformly rejected. See Carter v. McClaughry, 183 U.S. 365 (1902); Ebeling v. Morgan, 237 U.S. 625 (1915) ; Morgan v. Devine, 237 U.S. 632 (1915) ; Albrecht v. United States, 273 U.S. 1 (1927) ; Blockburger v. United States, 284 U.S. 299 (1932); United States v. Michener, 331 U.S. 789 (1947); Pereira v. United States, 347 U.S. 1 (1954). Nor does Ex parte Lange, S5 U.S. (18 Wall.) 163 (1883), bring multiple sentences within the sweep of the double jeopardy clause. Lange held that the Constitution barred double punishment for the same offense; but the case involved two proceedings, and the sentence at the second was imposed after the first sentence had heen ex:ecuted. Moreover, the sentences were rendered under the same verdict for the same statutory offense and the same act, whereas multiple sentence cases involve either different statutory offenses, see, e.g., Morgan v. Devine, supra, or different acts, see Ebeling v. Morgan, supra, and the sentences are imposed under different verdicts on separate counts.

18. To equate "act" or "transaction" with "offense," as it appears in the double jeopardy clause, might unduly limit the legislature's power to declare conduct criminal and to punish it reasonably. Where two statutes apply to the same conduct, the legislature may intend cumulative punishment, particularly if multiple violations produce greater social harm than if only one statute had been violated-e.g., where the statutes vindicate different social norms, see notes $48-53$ infra accompanying text. And "there is nothing in the Constitution which prevents Congress from punishing separately each step leading to the consummation of a transaction which it has power to prohibit and punishing also the completed transaction." Albrecht v. United States, supra note 17 , at 11. But the fact of such congressional power does not settle multiple sentence questions. For, "when Congress has the will it has no difficulty in expressing it-when it has the will, that is, of defining what it desires to make the unit of prosecution and, more particularly, to make each stick in a faggot a single criminal unit. When Congress leaves to the Judiciary the task of imputing to Congress an undeclared will, the ambiguity should be resolved in favor of lenity." Bell v. United States, 349 U.S. 81, 83 (1955) (reversing consecutive sentences on two Mann Act counts, each count referring to a different woman where the trip and the car involved were the same).

But see Comment, 65 Y ALE L.J. 339, 340 (1956), urging that double jeopardy has two meanings: (1) prohibition of double prosecutions for a single act or activity, and (2) prohibition of punishment "more severely than the law provides, through the device of finding . . . several violations of substantive law where only one exists." However, since much of the confusion in multiple sentence cases is directly attributable to use of traditional double jeopardy tests, see notes 21-23 infra and accompanying text, this approach might perplex more than it clarifies. On a verbal level, at least, a defendant who is sentenced at a single trial would not seem to be twice in jeopardy. See Kokenes v. State, 213 Ind. $476,480,13$ N.E.2d 524, 526 (1938): "The contention that the conviction on the first count bars a conviction on the second is untenable, since the convictions 
Nevertheless, multiple sentence cases are often misdirected by the "same evidence" test, a judicial gloss on the double jeopardy clause. ${ }^{19}$ Developed as an antidote to defense claims of variance in an era of pleading formalism, ${ }^{20}$

were simultaneous, and there was no former jeopardy." Moreover, the dual approach is at times mutually exclusive; and the idea that rape and incest, for instance, might be considered two "offenses" for purposes of punishment at a single trial under double jeopardy test (2) but one "offense" for purposes of two prosecutions under double jeopardy test (1), see Comment, 65 Y ALE L.J. 339, 346 (1956), requires unusually careful analysis. Finally, to extend and subdivide double jeopardy might detract from its basic importance. See Kirchheimer, The Act, the Offense and Double Jeopardy, 58 Yale L.J. 513,526 (1949): "Suffering a complete new trial for substantially the same set of facts would seem to involve a larger question of principle than the possibility of the defendant's serving an aggravated sentence because the court failed to consider the logical relationship of the various offenses and erroneously made the counts run consecutively."

On the ather hand, posing the problem simply as a question of legislative intent has few drawbacks. It might foreclose habeas corpus review, available under a double jeopardy rationale. See Peters, Collateral Attack by Habeas Corpus, 23 Wasr. L. Rev. 87, 91-92 (1948). But an alternative procedure is available for attacking sentences in the federal courts. See 28 U.S.C. $\S 2255$ (1952). And, from a practical standpoint, habeas corpus review in state courts may be minimal. See, e.g., Alcorta v. Texas, 355 U.S. 28 (1957) (reversing, on due process grounds, Texas Court of Criminal Aippeals denial of habeas corpus petition where defendant's death sentence was based on perjured evidence knowingly elicited by the prosecutor); Statement of Hon. Carl V. Weygandt, C.J., Supreme Court of Ohio, Hearings Before Subcommittee No. 3 of the House Committee on the Judiciary on H.R. 5649, 84th Cong., 1st Sess. 13 (1955): "Our penitentiary has as many curbstone lawyers as any other State penitentiary, but we at least have a consistent record in Ohio that we have never allowed one of these writs of habeas corpus." See also Shaefer, Federalism and State Criminal Prosecution, 70 HARv. L. REv. 1, 16-17 (1956) (suggesting that prison practices may in many states give prisoners limited access to the courts). And it may even be possible to obtain habeas corpus review on due process grounds. Such protection has been afforded where, for example, a prisoner is serving ten years for a crime carrying a maximum sentence of five years. See Note, $9 \mathrm{U}$. FLA. L. Rev. 348 (1956) (collecting cases).

19. See note 17 supra. Even where consecutive sentences have been reversed, whether under a same transaction or lesser included offense rationale, double jeopardy is either only referred to in passing or not referred to at all. See United States v. Chiarella, 187 F.2d 12 (2d Cir. 1951); Schroeder v. United States, 7 F.2d 60 (2d Cir. 1925) ; Stevens v. MeClaughry, 207 Fed. 18 (Sth Cir. 1913). But see Tritico v. United States, 4 F.2d $66+$ (5th Cir. 1925) (basing reversal of consecutive sentences squarely on constitutional grounds); Murphy v. United States, 285 Fed. 801, 817 (7th Cir. 1923) (same). For criticism of the same evidence test as applied in double prosecution cases, see Iugar, supra note 16, at 318 ("double jeopardy as currently applied ... does not appeal to the average person's sense of fair play") ; Kirchheimer, supra note 18; Comment, 65 YaLE L.J. 339, 344-49 (1956); Note, 24 MrNN. L. REv. 522 (1940). See also treatment of the problem in Moder. Penal Code $\$ 110$, quoted note 16 supra.

20. Rex v. Vandercomb, 2 Leach 708, 168 Eng. Rep. 455 (Ex. 1796), was the forerunner of same evidence cases. In the first trial, a verdict was directed against the prosecution for variance and failure of proof, the court stating, "the form of the indictment decides the question." Id. at 711, 168 Eng. Rep. at 457. Although the original indictment had charged defendant with burglarously breaking and entering and stealing, a second prosecution and conviction for burglarously breaking and entering with intent to steal was allowed because "different" evidence was involved. See Kirchheimer, supra note 18, at 
the test bars a second prosecution only if the evidence required to prove the second offense is the same as that needed to establish the first. ${ }^{21}$ Strictly applied, the test offers no greater protection in multiple sentence cases than the double jeopardy clause it implements. So long as different statutory provisions are pleaded, different evidence will be necessary to prove the separate counts. ${ }^{22}$ Investigation thus concluded, appellate courts generally affirm con-

527-29; Comment, 65 Y YLE L.J. 339, 343-44 (1956). See also Sir Matthew Hale's complaint that "more offenders escape by the over easy ear given to exceptions in indictments, than by their own innocence," 2 Hale, Pleas of tre Crown 193 (Wilson ed. 1778); 1 Stephen, Crtarinal Law of England 284-8S (1883).

21. As it appeared in Rex v. Vandercomb, supra note 20, at 720, 168 Eng. Rep. at 461, the test stated: "[U]nless the first indictment were such as the prisoner might have been convicted upon by proof of the facts contained in the second indictment, an acquittal on the first indictment can be no bar to the second." For variations of the rule, see ALI DRAFT 26-27; Lugar, supra note 16, at 321-23; 7 BRooKLyn L. REv. 79, 82 (1937). As formulated in Blockburger v. United States, 284 U.S. 299, 304 (1932), "the test to be applied to determine whether there are two offenses or only one is whether each provision requires proof of a fact which the other does not."

22. The test emphasizes theoretical rather than factual separability. Although essentially the same evidence-testimony and exhibits-is in fact offered to prove two offenses, courts point out that the counts contain different words or refer to different statutes and demonstrate that hypothetically each count could be violated separately. See, e.g., Burton v. United States, 202 U.S. 344 (1906) (possible to "receive" an illegal bribe without "agreeing to receive" it); Ekberg v. United States, 167 F.2d 380 (1st Cir. 1948) (conceivable to imitate a federal officer and fraudulently "obtain" a typewriter without having fraudulently "demanded" it); United States v. Michener, 331 U.S. 789 (1947) (possible to "procure" counterfeiting plates for manufacture without "possessing" them); Albrecht v. United States, 273 U.S. 1, 11 (1927) : "[Possessing and selling liquor] are distinct offenses. One may obviously possess without selling; and one may sell and cause to be delivered a thing of which he has never had possession; or one may have possession and later sell, as appears to have been done in this case. The fact that the person sells liquor which he possessed does not render the possession and the sale necessarily a single offense." Emphasis on theoretical rather than actual evidence is most obvious in narcotics cases where proof of possession is prima facie evidence of violation of two different statutes. See note 11 supra; Corollo v. Dutton, 63 F.2d 7 (5th Cir. 1933). See also Martinez v. United States, 220 F.2d 740, 742 (1st Cir. 1955) : "[Defendant argues] proof of selling heroin knowing the same to have been imported contrary to law (count 2) establishes every essential element of selling the same heroin not in or from the original stamped package (count 1), for the reason that illegally imported heroin would of necessity not be in or from the original stamped package. We are not clear that this would be so. For instance, might not an importer, believing in good faith that he had complied with the conditions prescribed for lawful importation, pay the tax imposed by 26 U.S.C. $2550 \mathrm{a}$ and affix to the packaged drug the corresponding revenue stamp; in which case while the importation would still be contrary to law, would it nevertheless not be possible to make a subsequent sale of the drug in or from the original stamped package?"

Since strict application of the test would absolutely foreclose defendants, some courts balk at carrying the test to logical extremes. See Robinson v. United States, 143 F.2d 276, 277 (10th Cir. 1944) ("but the same evidence test must be applied with some discrimination"); District of Columbia v. Buckley, 128 F.2d 17, 21 (D.C. Cir. 1942) (concurring opinion; application of the same evidence test does not end the matter; must 
secutive sentences without inquiring whether cumulative punishment was contemplated by the legislature. ${ }^{23}$ Application of the same evidence test accordingly ranks mechanical doctrine above the gravity of the criminal conduct and examination of the ultimate authority for imposition of punishment-the will of the legislature. ${ }^{24}$

also determine whether the difference is "substantial" or "minor"); cf. Regina v. Brettel, Car. \& M. 609, 176 Eng. Rep. 656 (C.P. 1842) (although legally possible, "it would be as well not to proceed with this indictment"). Or the test may be avoided by broad interpretation. Ballerini v. Aderholt, 44 F.2d 352 (5th Cir. 1930) (one sale of narcotics violating two statutes held to be but one "criminal act") (overruled in Blockburger v. United States, 284 U.S. 299, 304 (1932)) ; Copperthwaite v. United States, 37 F.2d 846 (6th Cir. 1930): "[T] he supporting evidence [possession of narcotics] does not so materially vary as to justify two punishments, merely because two inferences are attached by different statutes to the same evidential basis." The usual implications of the test may be evaded by conceding the existence of separately indictable offenses but disallowing consecutive punishment. Munson v. McClaughry, $198 \mathrm{Fed}$. 72 (8th Cir. 1912). Also the test may be ignored and the propriety of cumulative punishment decided by reference to legislative intent. See note 36 infra. Still another means of avoiding the impact of the same evidence test is to hold that one offense is necessarily included in another. Morgan v. United States, 294 Fed. 82 (4th Cir. 1923) (manufacture of moonshine whiskey necessarily includes having possession of the whiskey and possessing property designed for manufacture of moonshine). Differently phrased, this exception states that where one offense is necessarily "incidental" to another, double punishment should not be allowed. United States v. Chiarella, 187 F.2d 12 (2d Cir. 1951) (possession and receipt of counterfeit money incidental to sale); Schroeder v. United States, 7 F.2d 60 (2d Cir. 1925) (possession of liquor necessary and incidental to transportation of liquor); cf. In re Nielsen, 131 U.S. 176 (1889) (conviction for cohabitation bars prosecution for adultery because sexual intercourse a necessary ingredient of both offenses).

Strict application of the same evidence test could further reduce the small and uncertain number of lesser included offenses. Thus, the argument that "concealing" is incidental to "transporting" a stolen car can be rejected on same evidence grounds. See United States v. Hampden, 294 Fed. 345 (E.D. Mich. 1923). Compare Albrecht v. United States, supra, writh United States v. Chiarella, supra; Morgan v. United States, supra; Commonwealth ex rcl. Ciampoli v. Heston, $292 \mathrm{~Pa} .501,141$ Atl. 287 (1928).

Substitution of the "same transaction," see Stevens v. McClaughry, 207 Fed. 18 (8th Cir. 1913), for the same evidence rationale, while useful in multiple prosecution cases, see note 16 supra, would be inappropriate in multiple sentence cases. For such a test also overlooks the possibility that the legislature may intend that a single transaction be cumulatively punished.

23. See, e.g., United States v. Michener, supra note 22; Morgan v. Devine, 237 U.S. 632 (1915); Kendrick v. United States, 238 F.2d 34 (D.C. Cir. 1956) ; Ekberg v. United States, supra note 22. But see Prince v. United States, 352 U.S. 322 (1957), and Bell v. United States, 349 U.S. 81 (1955), multiple sentence cases decided on the basis of legislative intent, without reference to the same evidence test. The result is frequently automatic even though the appellate court objects to the trial judge's sentence as unduly harsh. See Blockburger v. United States, supra note 22, at 305 ; Beckett v. United States, 84 F.2d 731 (6th Cir. 1936): "The severity of the sentence has given us much concern. ... Nevertheless, we find ourselves powerless to intervene." Convicted of a $\$ 1,200$ mail fraud under a ten-count indictment, defendant in Beckett was given cumulative sentences aggregating twenty-five years and $\$ 22,000$.

24. See cases cited note 36 infra where consecutive sentences were held unwarranted by legislative intent although application of the same evidence test would have 
The recent case of Gore $v$. United States typifies appellate disposition of the multiple sentence problem. ${ }^{25}$ For a single narcotics sale, defendant received consecutive sentences on each of three counts-sale without a written order, sale from an unstamped package and facilitating the concealment and sale of illegally imported drugs. Applying the same evidence test, the court held that each count stated a different offense. Without further inquiry, the sentences were affirmed. ${ }^{28}$ The concurring opinion, however, recognized that Congress might not have intended consecutive sentences ${ }^{27}$ but was constrained to affirm by the Supreme Court decision in Blockburger v. United States. ${ }^{28}$ Blockburger, the leading precedent in both narcotics ${ }^{29}$ and multiple sentence cases, ${ }^{30}$ similarly utilized a same evidence test to decide almost identical issues. ${ }^{31}$

Apparently, Blockburger indulged a presumption of legislative intent to allow cumulative punishment of criminal conduct condemned by several statutory provisions. ${ }^{32}$ Since separate provisions independently prescribe penalties

defined multiple offenses. See also Burton v. United States, 202 U.S. 344, 377 (1906) ("legislature, not the court which ... define[s] a crime and ordain[s] its punishment"); In re Bonner, 151 U.S. 242 (1894) ("the law of our country takes care, or should take care, that not the weight of a judge's finger shall fall upon anyone except as specifically authorized") ; Ex parte McGuire, 135 Cal. 339, 343, 67 Pac. 327, 329 (1902) (disallowing consecutive sentences unless specifically authorized by the legislature); People ex rel. Tweed v. Liscomb, 60 N.Y. 559 (1875) (same).

25. 244 F.2d 763 (D.C. Cir. 1957), cert. granted, 355 U.S. 903 (1958).

26. Id. at 765-66.

27. Id. at 766-67.

28. 284 U.S. 299 (1932).

29. United States v. Brisbane, 239 F.2d 859 (3d Cir. 1956) ; United States v. Johnson, 235 F.2d 159 (7th Cir. 1956); Corollo v. Dutton, 63 F.2d 7 (5th Cir. 1933).

30. Pereira v. United States, 347 U.S. 1, 9 (1954); Rawls v. United States, 162 F.2d 798, 799 (10th Cir. 1947) ; United States v. Larney, 2 U.S.C.M.A. 563, 566, 10 C.M.R. 61, 64 (1953) ; State v. Lawrence, 146 Me. 360, 362, 82 A.2d 90, 92 (1951). But sec United States v. Beene, 4 U.S.C.M.A. 177, 178-79, 15 C.M.R. 477, 478-79 (1954) (rejecting Blockburger's "in vacuo" approach).

31. 284 U.S. at 304 ; see note 21 supra. Blockburger's invocation of the same evidence test was based on three cases, two of which, Gavieres v. United States, 220 U.S. 338 (1911), and Morey v. Commonwealth, 108 Mass. 433 (1871), involved double prosecution. 284 U.S. at 304. It affirmed consecutive sentences on Harrison Act counts of sale of narcotics from an unstamped package and sale without a written order although both counts referred to the same sale. Id. at 301. In Gore, however, a sentence on a third count of violating the Narcotics Drugs Import and Export Act, 35 Stat. 614 (1909), as amended, 21 U.S.C. \& 174 (1952), established by defendant's possession of the narcotics sold in violation of the Harrison Act, was also prescribed. But the addition of a third count should not be significant. Enacted as complementary means of dealing with different aspects of the same problem, see H.R. REP. No. 852, 67th Cong., 2d Sess. 7-8 (1922); H.R. Rep. No. 23, 63d Cong., 1st Sess. 1, 3 (1913) ; H.R. Doc. No. 33, 63d Cong., 1st Sess. 1, 5 (1913), the statutes have been made unitary for purposes of punishment. The Boggs Act, 65 StaT. 767 (1951), provided the same penalties for violations of either statute. Id. at 767,768 .

32. Blockburger alluded only vaguely to legislative intent, 284 U.S. at 305 ; and there is no evidence that Congress contemplated consecutive sentences in the event of a single 
for admitted violations, such a presumption has immediate superficial appeal. Moreover, any technique which permits, yet does not require, courts to impose consecutive sentences commends itself by providing the trial judge with flexibility in the sentencing process. ${ }^{33}$ However, neither justification for the Blockburger presumption appears persuasive. In the related area of lesser included offenses, courts have never imposed cumulative punishment. ${ }^{34}$ So viewed, the need for flexibility and the independence of the statutory provisions would seem to turn on the "includibility" of the several violations committed by the defendant. Significantly, the concept of included offenses reflects a continuum of culpability; flexibility is afforded by the concomitant legislative provision of penalties of varying intensity. ${ }^{35}$ While a presumption of legislative intent not to allow cumulative punishment would thus appear justified in cases involving included offenses, a converse presumption should not arise because the legislature did not attempt a comparative as well as comprehensive proscription of the many elements comprising the illicit behavior. Presumably recognizing the shortcomings of the Blockburger ration-

narcotics transaction that violated two statutory provisions. Moreover, the penal section of the Harrison Act was ambiguous. 38 STAT. 789 (1914) : "That any person who violates or fails to comply with any of the requirements of this Act shall, on conviction, be fined ...." The Boggs Act under which Gore was sentenced contains similar language. 65 Stat. 767, $76 \$$ (1951), 21 U.S.C. \$ 174 (1952), 26 U.S.C. § 2557 (1952). Compare Prince v. United States, 352 U.S. 322 (1957), reversing consecutive sentences where defendant had committed two statutory offenses and the relevant penal clause stated: "Whoever, in committing, or in attempting to commit, any offense defined in subsections (a) and (b) of this section, assaults any person, or puts in jeopardy the life of any person by the use of a dangerous weapon or device shall be fined ...." For recent Supreme Court treatment of ambiguous language in penal laws, see Bell v. United States, 349 U.S. 81,83 (1955), quoted note 18 supra; United States v. Universal C.I.T. Credit Corp., 344 U.S. 218, 221-22 (1952) : "But when choice has to be made between two readings of what conduct Congress has made a crime, it is appropriate, before we choose the harsher alternative, to require that Congress should have spoken language that is clear and definite. We should not derive criminal outlawry from some ambiguous implication." But see id. at 221 n.4 (distinguishing Blockburger).

33. See Note, 45 Harv. L. Rev. 535, 540-41 (1932). Of course, flexibility can also be achieved within the range of minimum to maximum sentences. See, generally, Note, 101 U. PA. L. REv. 257 (1952), describing the discretionary power possessed by sentencing courts, criticizing abuses and suggesting limitations. See also Harrison v. United States, 7 F.2d 259, 263 (2d Cir. 1925) ("it appears to us that the maximum sentence prescribed by Congress is intended to cover the whole substantive offense in its extremest degree, no matter in how many different ways a draughtsman may plead it") ; United States v. Drake, 250 F.2d 216, 217 (7th Cir. 1957) (Federal Bank Robbery Act creates a single offense with various degrees of aggravation permitting sentences of increasing severity).

34. For cases expressly refusing to cumulate in the area, see Rutkowski v. United States, 149 F.2d 481 (6th Cir. 1945); Costner v. United States, 139 F.2d 429 (4th Cir. 1943) ; Tritico v. United States, 4 F.2d 664 (5th Cir. 1925) ; Carter v. State, 229 Ind. 205, 96 N.E.2d 273 (1951) ; Commonwealth ex rel. Shaddock v. Ashe, $340 \mathrm{~Pa} .286,17$ A.2d 190 (1941); Kaufman v. State, 189 Tenn. 315, 225 S.W.2d 75 (1949).

35. See Costner v. United States, supra note 34, at 431 ; Note, 66 YALE L.J. 427 (1957) (homicide); Hall, General Principles of Criminal Law 181-84 (1947). 
ale, the Supreme Court has recently abandoned the presumption approach and upset nonnarcotics consecutive sentences revealed unwarranted by examination of legislative history. ${ }^{36}$

36. In Prince v. United States, 352 U.S. 322 (1957), reversing 230 F.2d 568 (5th Cir. 1956), defendant was consecutively sentenced for entering a bank with intent to commit a robbery and for robbery. The circuit court had affirmed, citing with approval a factually similar case, Rawls v. United States, 162 F.2d 798, 799 (10th Cir. 1947), which, in turn, had relied on Blockburger. In Prince, two statutory provisions had been violated and nothing on the face of the statutes dictated sentencing procedure where both violations were part of the same transaction. Nevertheless, the Court, reversing cumulative sentences after reference to legislative intent, found "consistent with our policy of not attributing to Congress, in the enactment of criminal statutes, an intention to punish more severely than the language of its laws clearly imports in the light of pertinent legislative history," that entry with intent to rob merged with the consummated robbery. 352 U.S. at 329.

A similar approach was used in Bell v. United States, 349 U.S. 81 (1955), reversing 213 F.2d 629 (6th Cir. 1954).

It has been suggested that the Supreme Court has abandoned the same evidence test in favor of the same transaction approach. Gore v. United States, 244 F.2d 763, 767 (D.C. Cir. 1957) (concurring opinion). But Bell and Prince emphasize the crucial importance of legislative intent and generally ignore the conceptual problem of defining "offense."

Judicial interpretation of criminal laws is generally not confined to the face of the statute. See Heydon's Case, 3 Coke 7a, 76 Eng. Rep. 637 (Ex. 1584) (object is to discover "the mischief and defect" contemplated and "what remedy the Parliament hath resolved and appointed to cure the Disease of the Commonwealth"); Prince v. United States, supra ("the gravamen of the offense is not in the act of entering. . . rather the heart of the crime is the intent to steal") ; cf. Panama Refining Co. v. Ryan, 293 U.S. 388, 439 (1935) (dissenting opinion) : "[T]he meaning of a statute is to be looked for, not in any single section, but in all the parts together and in their relation to the end in view."

Inherently continuous offenses also exemplify the importance of legislative intent in multiple sentence cases. A continuous criminal course of conduct constitutes only one offense. But inherent continuity is often not readily apparent. Compare Crepps v. Durden, Cowp. 640, 98 Eng. Rep. 1283 (K.B. 1777) (selling bread on Sunday a continuous offense); In re Snow, 120 U.S. 274 (1887) (cohabiting with more than one wife inherently continuous), with Johnson v. Commonwealth, $201 \mathrm{Ky} .314,256$ S.W. 388 (1923) (seventy-five poker hands in one evening seventy-five offenses) ; Byrd v. State, 72 Tex. Crim. 265, 162 S.W. 363 (1913) (each day's unlawful medical practice a separate offense). Nor does the single impulse concept constitute a useful distinction; for as long as different physical acts occur, each may be accompanied by a separate impulse. Compare Crepps v. Durden, supra; In re Snow, supra, with Badders v. United States, 240 U.S. 391 (1916) (mailing seven letters at the same time to effect a single fraudulent scheme constitutes seven offenses); Ebeling v. Morgan, 237 U.S. 625 (1915) (cutting six mail bags equals six offenses). A finding of inherent continuity has more properly been based on legislative intent to punish a course of conduct rather than single physical acts even though each act is a violation for which the defendant could have been indicted and convicted. See United States v. Universal C.I.T. Credit Corp., 344 U.S. 218, 222 (1952) (if Congress wanted to attach criminal penalties to each component of a course of conduct "it could easily have said so"); MODEL PENAL CODE $\S 1.08(1)$ (e) (conviction for multiple offenses barred if the offense defined prohibits a course of conduct "unless the law provides that specific periods of such conduct constitute separate offenses"). Blockburger also dealt 
Similar analysis demonstrates that, contrary to the assumption in Gore and Blockburger, Congress did not authorize consecutive sentences for each phase of an illicit drug transaction. Enacted under the commerce and revenue powers presumably to avoid constitutional objection, ${ }^{37}$ early narcotics laws were intended to eliminate nonmedical use and traffic in drugs. ${ }^{38}$ Consistently, enforcement, in no way geared to protecting the revenue, ${ }^{39}$ has been directed against "dope peddlers"; and proponents of supplementary narcotics statutes explicitly cite dope peddling as their target. ${ }^{40}$ At present, the penalties to be imposed on narcotics offenders are dictated by the amended Boggs

with the continuous course of conduct question. The Court relied on the separate impulse doctrine and, as it did in considering the allied question involving a single sale-the part of the opinion discussed in the text-failed to inquire into Congress's actual design, simply asserting that the Harrison Act was intended to penalize each indictable narcotics offense. 284 U.S. at 305. See also Greene v. United States, 246 F.2d 677 (D.C. Cir. 1957) (single bargain but two deliveries held two sales separately punishable on six counts). But see Blockburger v. United States, 50 F.2d 795, 799 (7th Cir. 1931) (dissenting opinion): "If in the detecting process the government sees fit to make an installment affair of it, I do not think the government is in a position to say each installment constitutes a crime."

37. See 43 Conv. Rec. 1396-1400 (1909). Nor were the legislators' apprehensions illfounded; the Harrison Act barely survived constitutional tests. United States v. Doremus, 249 U.S. 86 (1919) ; Alston v. United States, 274 U.S. 289 (1927) ; Nigro v. United States, 276 U.S. 332, 341 (1928) ("we must assume that it is a taxing measure, for otherwise it would be no law at all"). But in light of the expanded scope of the commerce clause, see United States v. Darby, 312 U.S. 100, 114 (1941), and because the narcotics laws are part of a scheme implementing treaty commitments of the United States, see H.R. Rep. No. 23, 63d Cong., 1st Sess. 2 (1913) ; Alston v. United States, supra at 292; King, supra note 7, at 116; Comment, 62 YALE L.J. 751, 760-63 (1953) ; cf. Missouri v. Holland, 252 U.S. 416 (1920), the constitutionality of the narcotics statutes could most likely be sustained without reference to their revenue features.

38. See authorities cited note 7 supra.

39. In 1956, for example, the administration costs of narcotics laws were $1 \frac{1}{2}$ times greater than revenues. TREasury Dep't, Traffic in Opiun and Other Dangerous DRUGS for the YeAr ENDED DEc. 31, 1956, 27 (1957). Moreover, legislative and administrative attempts to differentiate between addict-"possession"-Offenders and traffickers, see H.R. Rep. No. 2388, 84th Cong., 2d Sess. 2 (1.956) ; 102 Cong. Rec. 10688 (1956); $97 \mathrm{id}$. at $\$ 207$ (1951) ; Hearings, supra note 10, at 121, 141, evince concern with a problem unrelated to collection of the nominal one cent per ounce stamp tax, see INT. REv. CODE OF 1954, $\$ \$ 4701$ (a), 4771. Similarly, allowance of the death sentence, 70 STAT. 571 (1956), 21 U.S.C. 176(b) (Supp. IV, 1957), seems an unusual deterrent for tax evasion. 40. Hearings Bcfore the Subcommittee on the Control of Narcotics of the House Committee on Ways and Means, 82d Cong., 1st Sess. 48 (1951); 97 Cong. Rec. 8205-08 (1951); testimony of Narcotics Commissioner Anslinger, Hearings, supra note 10 , at 121, 123, 127; see Gore v. United States, 244 F.2d 763, 767 n.1 (D.C. Cir. 1957) (Bazelon, J., concurring) : "The legislative history of the Narcotic Control Act of 1956 supports the view that the penalties Congress was providing were for the composite act of drug-peddling, not for the separate counts into which a prosecutor's ingenuity could divide it. See also Report to the House Committee on Ways and Means From the Subcommittee on Narcotics, May 10, 1956, 2 U.S. CODE CONG. SERv. 3304 (1956) : It is recommended that the convicted narcotic peddler be sentenced to not less than 5 years for a first offense and not less than 10 years for a second or subsequent offense. (Emphasis added.)" 
Act of $1951 .{ }^{41}$ Under that act at the time of the Gore prosecution, sanctions ranged from not less than two years for a first narcotics offense to not less than five years for a second. ${ }^{42}$ If each guilty verdict resulting from the usual multiple indictment were intended as an index of punishment, a single sale of narcotics could yield a sentence of forty-five years on a first conviction on multiple counts ;3 yet the maximum sentence provided for a "third offender" was only twenty years. ${ }^{44}$ Not only does the Gore adaptation of the Blockburger approach thus render the provisions of the Boggs Act meaningless, it undermines the legislative objective to promote uniform sentencing procedure for narcotics violators. ${ }^{45}$ For the complex of varying indictments and consecutive or concurrent sentences it makes possible destroys any potential uniformity. ${ }^{46}$ Since the statutes defining narcotics violations and the Boggs Act

41. 65 STAT. 767 (1951), as amended, 21 U.S.C. $\$ 174$ (Supp. IV, 1957), INT. Rev. CODE OF 1954, § 7237.

42. 65 Stat. 767 (1951), 21 U.S.C. $\S 174,26$ U.S.C. $\S 2557$ (b) (1) (1952).

43. Such a sentence admittedly carries the same evidence test to an extreme, but, within the framework of the test, see notes 22,23 supra, a logical extreme, for each separate sentence might hypothetically be based on different evidence. A single sale of narcotics could elicit counts of: (1) purchase of narcotics from an unstamped package; (2) selling narcotics from an unstamped package; (3) dispensing narcotics from an unstamped package; (4) sale of narcotics without a written order form; (5) buying illegally imported narcotics; (6) receiving illegally imported narcotics; (7) concealing illegally imported narcotics; (8) facilitating the transportation of illegally imported narcotics; (9) selling illegally imported narcotics. See Int. Rev. Code of 1939, $\$ \$ 2553-54,53$ Stat. 271 (now INT. Rev. CoDE of 1954, $\$ \S 4704-05$ ) ; 35 StAt. 614 (1909), as amended, 21 U.S.C. $\$ 173$ (1952). And counts (1) and (5)-(9) could be proved merely by possession at the time of the sale. See note 11 supra. The same evidence approach permits imprisonment for 45 years; a second offender might be sentenced to prison for 90 years; while a third offense could be punished by a prison sentence of 180 years. See 65 STAT. 767 (1951), 21 U.S.C. \$ 174, 26 U.S.C. \$ 2557 (1952). Indeed, in Gore, defendant was sentenced from 3-15 years on a first conviction, while a second offender could be incarcerated no longer than 10 years. In Martinez v. United States, 220 F.2d 740 (1st Cir. 1955), an ingenious prosecutor fashioned thirteen counts out of a single narcotics sale, and separate sentences, some concurrent, were upheld on all counts. Fragmentation of the Narcotic Drugs Export and Import Act (see counts (5)-(9) in hypothetical, supra) was allowed because the statute "in the disjunctive established multiple offenses. . . . Congress intended to place its condemnation upon each distinct, separate part of every transaction ..." Id. at 742-43. For suggestion that imposition of consecutive sentences may in aggravated cases violate the constitutional prohibition of cruel and unusual punishment, see Kirchheimer, stipra note 18, at 513-14 n.2.

44. 65 STAT. 767 (1951), 21 U.S.C. $\S 174,26$ U.S.C. $\S 2557$ (b) (1) (1952).

45. H.R. REp. No. 635, 82 d Cong., 1st Sess. 1-2 (1951).

46. The defendant in Gore, a first offender, was sentenced to from 1-5 years on three counts, the sentences to run consecutively. Although 1-5 years does not appear to satisfy the statutory minimum, see note 41 supra, it represented a compromise dictated by the District of Columbia indeterminate sentence laws, see D.C. CoDE ANN. $\$ 24-203$ (Supp. 1957). Since a minimum sentence can not exceed one third of the maximum in the District, the 2-5 years required by the narcotics laws would be illegal. However, the indeterminate sentence law provides that parole may not be granted until the minimum has been served. Because the maximum sentence must be at least three times the minimum, 
providing relevant penalties both contemplate proscription of a course of conduct, consecutive sentences should not be imposed when the prosecution frames an indictment isolating the segments of the total transgression. ${ }^{47}$

In other contexts, a legislative intent to proscribe a course of conduct rather than its elements may not be readily discernible. Particularly will this be true of overlapping statutes obviously enacted without reference to one another. Indeed, investigation under these circumstances will most likely reveal no specific evidence of legislative intent. When confronted with a prosecution involving such unrelated offenses, the courts may have greatest success in divining legislative purpose if they consider the social norms vindicated by the relevant statutory provisions. ${ }^{48}$ Vindication of a single social norm should,

it was considered the "real" sentence and analogized to an ordinary federal sentence under which parole may be extended after one third of the time has been served. See 18 U.S.C. $\S 4204$ (1952). Thus, the 1-5 year sentence was said to satisfy the Boggs Act requirement of a 2-year minimum because 5 years is the "real" sentence. See Hearings, supra note 10 , at 1260-61. Since Gore is not eligible for parole for 3 years, his sentence is approximately equivalent to a 9-year sentence in any other federal district. Congress has since provided that the District's indeterminate sentence laws are inapplicable in naroctics cases. 70 STat. 569 (1956), INT. Rev. CODE of 1954, $\S 7237$ (d) (2). On the desirability of uniform sentencing generally, see Wyzanski, $A$ Trial Judge's Freedom and Responsibility, 65 Harv. L. Rev. 1281, 1292 (1952) ; U.S. Dep't of Justice, Federal Prisons 1957, 1-3 (1958).

47. Comparison with sentences imposed for other crimes aids evaluation of legislative intent in the Boggs Act. In the House Committee Report, narcotics sentences were said to be inadequate when compared with crimes "of equal social significance." For a compilation of minimum mandatory sentences in twenty-four states (Alabama through Montana), see Hearings, supra note 10, at 1466 . The averages are approximately: arson: $1 \mathrm{r} / 2$ years; burglary : 3 years; forgery : 11/2 years; larceny : 1 year; kidnapping: 1ife imprisonment; rape: 8 years (equating two life imprisonments and one death sentence to 45 years each); robbery: 5 years. Although the soundness of the congressional approach to the narcotic addiction problem has been questioned, see Finestone, Narcotics and Criminality, 22 Law \& Contemrp. Prob. 69, 79-83 (1957); Lindesmith, The British System of Narcotics Control, 22 Law \& Contemp. Prob. 138, $146-49$ (1957) ; King, supra note 7, Congress without doubt considers narcotics violations particularly odious, see, e.g., 70 STAr. 571 (1956), 21 U.S.C. $\$ 176$ (b) (Supp. IV, 1957) (authorizing death sentence for sales of heroin to persons under eighteen). Under present laws, a first offender could, on the single count conviction of sale without a written order, receive a 20-year no-parole sentence. See INT. REv. CODE OF 1954, § 7237(d) (1.). Such a sentence would generally be equivalent to three times that possible for bank robbery. See Federal Bank Robbery Act, 18 U.S.C. $\S 2113$ (1952) ; Prince v. United States, 352 U.S. 322 (1957); United States v. Drake, 250 F.2d 216 (7th Cir. 1957) ; Federal Parole Act, 18 U.S.C. $\$ 4202$ (1952). A federal prisoner under sentence of life, or of 45 years or more, is eligible for parole after 15 years. Ibid. Thus, a 20-year no-parole sentence on one count could in effect be more severe than a life sentence.

48. See United States v. Beene, 4 U.S.C.M.A. 177, 15 C.M.R. 477 (1954).

Different tests may be appropriate in gauging legislative purpose in other multiple sentence cases. See note 5 supra. Thus, cumulative sentences may be intended where defendant's conduct results in physical injury to several individuals. See Ladner v. United States, 230 F.2d 726 (5th Cir. 1956), aff'd per curiam, 355 U.S. 282 (1958) (consecutive sentences allowed where a single shotgun blast wounded two federal officers). A different 
consistent with the concept of lesser included offenses ${ }^{49}$ and the current adaptation of merger and consummation, ${ }^{50}$ be suggestive of an intent not to allow cumulative punishment. ${ }^{51}$ For example, assault with a deadly weapon and illegal possession of a firearm each assert society's interest in protection of the person; consequently, punishment geared to the graver rather than the sum of offenses should fulfill the community's penological objectives. ${ }^{62}$ In contrast, a single act which violates laws prohibiting Sunday sales and liquor

test may prevail where property interests are concerned. See United States v. Taylor, 6 U.S.C.M.A. 289, 20 C.M.R. 5 (1956) (only one punishable larceny where severa1 articles, the property of different persons, were stolen at the same time and place). Contra, Oddo v. United States, 171 F.2d 854 (2d Cir. 1949) (separately punishable charges permitted where defendant stole a truck containing merchandise consigned to different owners). For discussion of various possible tests, see Kirchheimer, supra note 18; Horack, The Multiple Consequences of a Single Criminal Act, 21 MINn. L. Rev. 805 (1937) ; Comment, 65 YALE L.J. 339, 363-68 (1956).

For a general discussion of legislative intent problems, see Bickel \& Wellington, Legislative Purpose and the Judicial Process: The Lincoln Mills Case, 71 HARv. L. Rev. 1, 14-18 (1957). While judicial interpretation of legislative intent may ordinarily be corrected by the legislature, "permanent institutional attributes" occasionally render correction impracticable. Thus, Congress was not realistically allowed the last word when the Court found that the Mamn Act applied to polygamy, since congressional reversal would have appeared tantamount to condoning polygamy. Id. at $17 \mathrm{n} .67$.

49. See notes 34-35 supra and accompanying text.

50. At common law, misdemeanors were merged with felonies when charged in the same indictment. A misdemeanor defendant had procedural rights denied an accused felon. Thus, merger prevented the felon from profiting because his conduct also constituted a misdemeanor. This rule has been eliminated by statute or decision in most states. MILIER, Criminal Law 51 (1934). But see People v. Vollmer, 299 N.Y. 347, 349, 87 N.E.2d 291, 292 (1949) (misdemeanor assault "a component of, and merged into, the homicide on trial"). However, modern commentators have urged and some criminal codes provide that where a defendant is convicted of both attempt (or conspiracy) to commit a crime and commission of that crime, the attempt is "merged" (or the conspiracy is "consumed") and only a single punishment may be imposed. WIs. Stat. \& 939.72 (1955); ModEr Peatal Code $\$ \S 1.08(1)$ (a), (b); Kirchheimer, supra note 18, at 517-22; see Prince v. United States, 352 U.S. 322, 328 (1957) (entry with intent to rob "merged" with robbery; based on congressional intent); Brooks v. United States, 223 F.2d 393, 394 (10th Cir. 1955); Commonwealth ex rel. Tokarchik v. Claudy, 174 Pa. Super. 509, 513, 102 A.2d 207, 209 (1954); cf. Lugoz, Commentaire du Code Penal Suisse art. 68 (1939) (if defendant sentenced for more than one offense, penalty limited to no more than one and one-half times the maximum for the most serious offense); Grant, The Lanza Rule of Successive Prosecutions, 32 Colum. L. Rev. 1309, 1323 (1932) (asserting that under French law defendant may be tried and convicted of two or more distinct offenses growing out of a single line of conduct but may only be punished for the most severe).

51. For classifications of social norms, see Dession, Criminal Law AdninistraTION AND PUBLIC ORDER viii (1948) (offenses against the person or reputation: deprivations of well being and respect; offenses against property: deprivations of wealth; offenses against authority: deprivations of power; offenses against morality: deprivations of rectitude) ; Allen, The Nature of a Crime, 13 J. CoMp. LEg. \& InT'L L. (3d ser.) 1, 24-25 (1931).

52. Application of the same evidence test, of course, yields the opposite result. See Kendrick v. United States, 238 F.2d 34 (D.C. Cir. 1956). 
sales to minors would be cumulatively punishable since one statute vindicates religious values, and the other is directed toward protecting minors. ${ }^{53}$ The various objectives of criminal law-reformation, rehabilitation, retribution, isolation and deterrence ${ }^{54}$-are also relevant in determining probable, but unexpressed, legislative design. For instance, if fragmentation would increase a forty-year maximum sentence to three hundred and sixty years, the more severe penalty is unlikely to serve any purpose not already fulfilled. ${ }^{\text {55 }}$ Acting in a context which limits punishment by the will of the body that defines crime, courts in multiple conviction cases should abandon automatic and inappropriate application of the same evidence test and focus on legislative intent instead.

53. See Comment, 65 YaLE L.J. 339, 364 (1956); ALI Draft 16 (condoning double prosecution); Ruble v. State, 51 Ark. 170, 10 S.W. 262 (1888) (same); Commonwealth v. Vaughn, $101 \mathrm{Ky} .603,42$ S.W. 117 (1897) (same). However, multiple prosecutions may not be allowed under modern pleading rules requiring joint indictment for offenses arising out of the same transaction, see note 4 supra, even though separate punishable offenses have been committed, see note 17 supra and accompanying text.

Although the majority of multiple sentence cases would probably involve, as Gore did, statutory provisions implementing the same social norm, exact definition is sometimes difficult. See, e.g., United States v. Dicario, 8 U.S.C.M.A. 353, 362, 24 C.M.R. 163, 172 (1957) (dissenting opinion; mail theft and larceny offend different norms).

54. See Michael \& WeChsler, Criminal Law and Its Administration 1-17 (1940); Hall \& Glueck, Crminal Law 19-24 (1940). In the narcotics context, reformation and rehabilitation are particularly pertinent. A majority of convicted and sentenced narcotics peddlers are addicts who become "pushers" in order to pay for their own supply. See Hearings, supra note 10, at 1225. Proper treatment of an addict takes an average of four and one-half months; and extended incarceration may have an adverse effect upon the convict-patient. Testimony of Dr. Harris Isbell, Director, Research Division, U.S. Public Health Service Hospital, Lexington, Ky., Hearings, supra note 40, at 199. Nevertheless, the main purpose of narcotics legislation appears deterrent and retributive. H.R. Rep. No. 635, 82d Cong., 1st Sess. 4-5 (1951); 97 CoNg. Rec. 8204-09 (1951) ; H.R. Rep. No. 2388, 84th Cong., 2d Sess. 64 (1953); 70 Stat. 571 (1956), 21 U.S.C. $\$ 176$ (b) (Supp. IV, 1957) (permitting imposition of death sentence for sale or gift of heroin to juveniles). However, the deterrent effect of narcotics laws on addict-sellers is questionable. See Statement of James V. Bennett, Director, Federal Bureau of Prisons, Hcarings, supra note 10, at 1218: "[The addict] has lost his power to resist drugs and no amount of punitive treatment can deter him."

55. Under present narcotics laws, for example, a third offense may be punished by a no-parole sentence of forty years and a fine of $\$ 20,000$. 70 STAT. 570 (1956), 21 U.S.C. $\S 174$ (Supp. IV, 1957), INT. REv. CODE of 1954, § 7237. Thus, consecutive sentences could yield up to 360 years and fines totalling $\$ 180,000$. See note 43 supra. 